transfusion of blood as a remedial measure. How well founded his confidence was is shown by the brilliant success which has attended Mr. Lane's bold adaptation of the treatment. I only once saw transfusion of blood attempted, and that was for a case of pernicious anæmia under the care of Dr. Wilks. Notwithstanding the fact that it was tried under the most favourable circumstances, with all the necessary apparatus ready, with skilled help at hand, and plenty of time, yet through premature clotting and various other mishaps it ended in a complete failure, probably not one drop of blood reaching its destination. I remember I came to the conclusion at the time that transfusion was not an operation I should care to attempt in an emergency, even if $I$ had the expensive apparatus required at hand.

I should think that, owing to the simplicity of Dr. Wooldridge's method, it should be given a fair trial, and in order that any general practitioner like myself may be able to avail himself of it in an emergency, $I$ hope that Mr. Lane may find time on a future occasion to give us fuller particulars as to the method of carrying it out than he has afforded us in the account published in the last number of THE LANCET. It would be important to have fuller information regarding: (1) the apparatus required and mode of use; (2) the composition and temperature of the saline solution; (3) the time occupied in the injection-or, in other words, the rate at which it is safe to throw such a large volume as three pints and a half of fluid into the general circulation; (4) any hints which his experience may suggest.

I may add for the benefit of any old Guy's men in India, that it was Dr. Wooldridge's hope that his method might some day be applied to the "collapse" stage of cholera. He thought that the unfortunately transitory, though brilliant, results of intravenous injection of saline solutions in that disease were due to the effect not being kept up. His idea, therefore, was to have a large quantity of the solution hung over the patient's bed and allow a constant flow to run through the vein, the rate being regulated by the effects produced, and so keep up the volume of the blood and counteract the constant drain of its watery constituents through tbe intestines. It was his opinion that, at any rate, the patient would escape the risk of dying through his blood becoming inspissated. His first theory having been proved to be correct by Mr. Lane, it remains the privilege of some of your colonial readers who happen to have known Dr. Wooldridge and admire his genius, to show us that his second theory is as brilliant as his first.

I am, Sirs, yours faithfully, FANCIS HEATHERLEY, B.S., F.R.C.S.

New Ferry, Sept. 13th, 1891.

\section{THE EASTERN HOSPITALS INQUIRY.}

\section{To the Editors of THE LANCET.}

Sins,-Referring to your leading article on the Eastern Hospitals Inquiry, amongst other matters you allude to the subject of disinfection, which has been employed there for a period of twenty years. During this time the bed linen \&c. of over 25000 patients have been washed, and a large number of persons, young and susceptible to infectious diseases, have been employed. The following are the diseases to which they have been exposed (small-pox excluded): iyphus ferer, enteric fever, scarlet fever, measles, diphtheria, and glanders; but with three exceptions, to be mentioned hereafter, no case of infectious disease has arisen during this long period amongst the laundry staff. One of the exceptions was the head laundress, whose business it was to visit the wards, and who possibly contracted it in this way or possibly elsewhere, not in the hospital at all. It is a mistake to suppose that all cases of infectious disease which "develop" in an infectious disease hospital "arise" there. The other two exceptions were the cases of two sisters, who were employ ed for two years at the soiled linen tub. They had been dealing during that time with the most infected of the linen \&c. with complete immunity from infectious disease. At the end of that time, however, the brother of the young man of one of these sisters was admitted with enteric fever, and she visited him, soon after which she developed enteric fever. She was placed in an enteric ward, where she was visited by her sister, soon after which this other sister developed enteric fever. These three cases occurred about twelve years ago, since which time 'not a case of infectious disease has appeared amongst the laundry staff. Judging, then, of $m y$ method of disinfection by results, it is proved to be efficient. I have more than once called the attention of
Dr. Bridges and of the many distinguished health officers and physicians who have from time to time visited the bospital from all parts of the world to the doubtful value of the current disinfectants, to the complete efficiency of this method, and to the fact that a valuable contribution had been made to medical science.

I am, Sirs, yours obediently,

Homerton, Sept. 14th, 1891. Álex. COLlite.

\section{BURIAL OR CREMATION?}

\section{To the Editors of THE LANCET.}

SIRS,-I would wish to supplement your admirable re. marks in THE LANCET of Aug. 29th, p. 497, with a few suggestions of my own, the result of many years' study of the subject. Personally I am in favour of "earth to earth" burial as the means of disposal of the dead, but that cremation is the more perfect mode, speaking sanitarily, does not appear to me to admit of argument. I have therefore ever since the appearance of Sir Henry Thompson's celebrated paper in 1874, contended that those who prefer cremation as the mode in which their own bodies should be disposed of ufter death should have every facility for this being done. Extreme statements have been made by partisans on each side as to the objectionable features of burial and of cremation respectively. You have disposed of the former so effectually that i will merely add this remark. If burial were so dangerous as the cremationists urge, every village in which there is a churchyard or chapel. yard still in use ought to be a hotbed of disease, and this we know is not the fact. Where burials are few, in simple cotlins and earthen graves, the ground will last for centuries without any detriment to the living. Burial, in the literal sense of the word, is really cremation underground; to condemn it is absurd.

But, on the other hand, the advocates of burial are equally absurd, it seems to me, in attempting to make so much capital ont of what may be termed the medicolegal objection; for if every body is to be buried with a view to its being exhumed, farewell to burial reform. It would be an argument in favour of lead cottins, vaults, and all the mockeries of burial against which THE LANCET has inveighed so long. It is, however, capable of the reductio ad absurdum all round. Deaths occur daily in hundreds throughout the country of the perfectly natural cause of which there is not a shadow of a doubt. Again, it would be easy to name several poisons which could not by any chemical process be discovered, even soon after death and burial. What is required is an improvement in our death certification and registration system. Following an old and wise saying, let us take care of the pence-i.e., the ordinary cases of death-leaving the pounds-the extraordinary cases, requiring exhumation-to take care of them. selves. As you have hinted, the two systems may be permitted to continue side by side; but as the principle of burial reform in its most important feature of "earth to earth" has been generally admitted, it seems to me that members of our profession, and especially medical officers of health, should do their ntmost to suppress the following evils which still exist :-

1. Burials underneath cathedrals, churches, chapels, or buildings where people are assembled to worship. Those who order such entombments, for it is a mockery to term them burials, do so from thoughtlessness and under a mis. taken notion of vested rights and the powers conferred by a "faculty." No faculty, whether granted by a clerical or legal chancellor, can confer the right to do an improper thing, and the Home Secretary has power to overrule any such faculty. Several City churches have been compuls orily closed in consequence of the effluvia arising from the human remains in the vaults beneath. And yet, in spite of this, the officials of another City church obtained a faculty to re-inter the remains removed from the churchyard into the crypts under the church. Such proceeding was strongly condemned in THE LANCET, and I have reason for believing that it was in consequence of this that the Home Secretary intervened and prohibited the proceeding. In another casethat of the Bebington Church, Cheshire-the combined action of the rector, churchwardens, medical officer of health, and parishioners prevented the granting of a faculty for burying a body in a vault beneath the church. But even if the faculty had been granted, the interment would, I feel sure, have been forbidden on application to the Home Office. It is too late in the day to make church vaulb channel houses, 